\title{
Ecological dynamics of two remote Alpine lakes during ice-free season
}

\author{
Rocco TIBERTI,${ }^{1,2 *}$ Sabino METTA, ${ }^{3}$ Martina AUSTONI,${ }^{4}$ Cristiana CALLIERI, ${ }^{4}$ Giuseppe MORABITO,${ }^{4}$ \\ Aldo MARCHETTO, ${ }^{4}$ Michela ROGORA, ${ }^{4}$ Gabriele A. TARTARI,${ }^{4}$ Jost VON HARDENBERG, ${ }^{3}$ \\ Antonello PROVENZALE ${ }^{3}$
}

${ }^{1}$ Dipartimento di Scienze della Terra e dell'Ambiente, Università di Pavia, Via Ferrata 9, 27100 Pavia; ${ }^{2}$ Alpine Wildlife Research Centre, Gran Paradiso National Park, Degioz 11, 1101 Valsavarenche; ${ }^{3}$ Istituto di Scienze dell'Atmosfera e del Clima, Consiglio Nazionale delle Ricerche, ISAC-CNR, Corso Fiume 4, 10133 Torino; ${ }^{4}$ Istituto per lo studio degli ecosistemi, Consiglio Nazionale delle Ricerche, ISE-CNR, Largo Vittorio Tonolli 50, 28922 Verbania Pallanza, Italy

*Corresponding author: rocco.tiberti@gmail.com

\begin{abstract}
We studied hydrochemistry and plankton dynamics in two remote Alpine lakes: lake Nivolet superiore (2530 m asl) and lake Trebecchi superiore (2729 $\mathrm{m}$ asl) in the Gran Paradiso National Park (Western Italian Alps) in summer 2009. The aim of this study was to enhance the understanding of natural ecological dynamics in the pelagic habitat of Alpine lakes by enlarging the number of biotic and abiotic variables usually considered to this end and by increasing the frequency of samplings, generally low in remote lakes. During the eight samplings performed in 2009, chemical and physical variables were measured both in situ and in the laboratory. We also followed the dynamics of all the compartments of the naturally simplified trophic chain of the two lakes from pico-prokaryotes to phytoplankton and zooplankton. Our results confirm the oligotrophic, close-to-pristine state of lake Nivolet and lake Trebecchi as they are not affected by hydromorphological alterations, they are naturally fishless and are not sensitive to acidification risk and acidity pulses. On the other hand, the two lakes have distinct abiotic conditions due to their glacial origin and to the lithological composition of their watersheds. We found some differences in the spatial variation of pico-prokaryotes, phytoplankton and zooplankton due to the different mixing regimes and maximum depth of the two lakes. Conversely, temporal patterns were similar in both lakes, related to ecological interactions and to changes in the abiotic conditions. The rapid succession of events in extreme ecosystems, such as the Alpine lakes studied here, confirm the predominant role of external environmental factors (e.g., the duration of the ice-free season) and of ecological interactions among different trophic compartments. This research underlines the importance of seasonal niche partitioning among organisms with different size.
\end{abstract}

Key words: lake chemistry, bacteria, phytoplankton, zooplankton, Gran Paradiso National Park.

Received: November 2012. Accepted: February 2013.

\section{INTRODUCTION}

Alpine lakes are remote ecosystems, exposed to harsh climatic conditions (Straskabova et al., 1999a; Catalan et al., 2006). Under the ice, a peculiar overwintering community can develop (Salonen et al., 2009), but a large variety of aquatic organisms are constrained to complete their life cycle within a short ice-free season before the lakes freeze and turn into dark heterotrophic systems, isolated from the surrounding terrestrial habitats for most of the year.

The rapid environmental changes of Alpine lakes lead to non-stationary summer dynamics (Ventura et al., 2000), so that frequent samplings are necessary to delineate a realistic pattern of plankton communities. Although the main seasonal patterns have been described for high altitude lakes in the Alps (Pechlaner et al., 1970; Tilzer and Schwarz, 1976; Mosello et al., 1992; Callieri and Bertoni, 1999; Winder et al., 2003; Salcher et al., 2010) and in other mountain regions (Capblancq and Laville, 1983; Mcknight et al., 1990; Pienitz et al., 1997a, 1997b; Ventura et al.,
2000; Ellis et al., 2003), the understanding of their seasonal variability is still partially limited by the piecemeal approach which is commonly used and by the specific ecological features of the lakes, which are often directly or indirectly impacted by human activities (e.g., acidified lakes or lakes stocked with alien fish) (Mosello et al., 1992; Winder et al., 2003). Indeed, high-altitude lakes can be frequently exposed to several anthropogenic threats, such as water exploitation (CIPRA, 1992; Godlewska et al., 2003), alien species introduction (Eby et al., 2006; Magnea et al., 2013), climate change (Rogora et al., 2003) and long range atmospheric transport of air pollutants (Ørbæk et al., 2007). As a result, it is difficult to find a truly pristine lake in some mountain regions. For example, in the mountain lakes of Western United States, Bahls (1992) estimated that $95 \%$ of lakes deeper than $3 \mathrm{~m}$ contained non-native trout. Furthermore, only one or few ecological compartments are studied at a time (Mcknight et al., 1990; Callieri and Bertoni, 1999), so that in general it is difficult to fully understand the lake ecosystem functioning. 
To overcome at least some of these shortcomings, we planned an intensive sampling campaign (fortnightly from July to October) in two high mountain lakes located in the Gran Paradiso National Park, providing the measurement of climatic, chemical and physical variables and the study of the pico-prokaryotic, phytoplanktonic and zooplanktonic communities. The aim of this study was to enhance the understanding of natural ecological dynamics in the pelagic habitat of Alpine lakes by enlarging the number of biotic and abiotic variables usually considered to this end. We chose lake Nivolet superiore (NIV) and lake Trebecchi superiore (TRS) as study sites because they are naturally fishless, and, as shown by a first study which included many lakes of the Gran Paradiso National Park (Tiberti et al., 2010), they resulted not sensitive to acidification risk and to acidity pulses and not significantly affected by long range transport of atmospheric pollutants, such as nitrogen compounds. We expected to find differ-

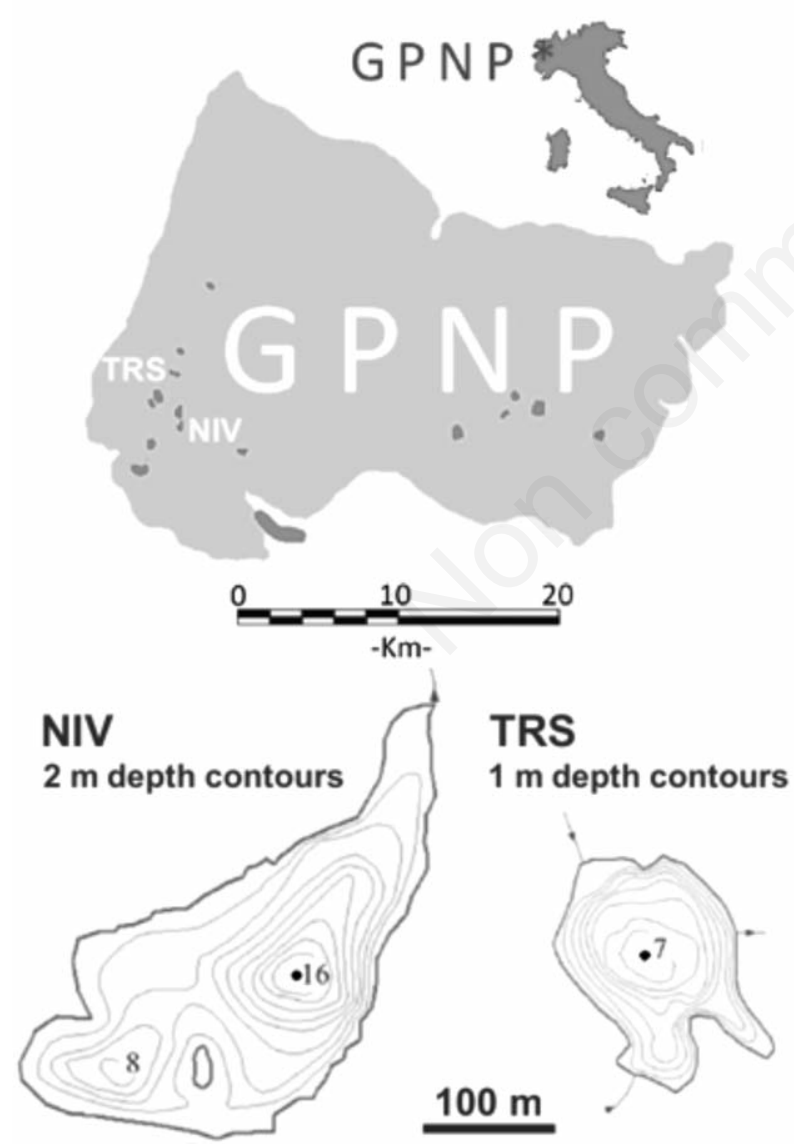

Fig. 1. Map of the Gran Paradiso National Park (Western Italian Alps) and bathymetries of lakes Nivolet superiore (NIV) and Trebecchi superiore (TRS). Black dots indicate the sampling sites at maximum depth point for each lake. ent ecological assemblies or dynamics in these two lakes since they offer distinct abiotic conditions due to their distinct glacial origin and to the different lithological composition of their watersheds.

\section{METHODS}

\section{Study area}

Lake Nivolet superiore ( $\left.45^{\circ} 28^{\prime} 54^{\prime \prime} \mathrm{N}, 07^{\circ} 08^{\prime} 41^{\prime \prime} \mathrm{E}\right)$ and TRS $\left(45^{\circ} 30^{\prime} 07^{\prime \prime} \mathrm{N}, 07^{\circ} 08^{\prime} 40^{\prime}\right.$ " E) belong to the catchments of the Dora di Savarenche stream, entirely located in the Gran Paradiso National Park (Western Italian Alps) (Fig. 1). The lakes are not affected by hydromorphological alterations, are larger than one hectare and are both located above the local timberline, with their watershed belonging to the Alpine and nival belts.

Lake Nivolet superiore is a tarn with its water level risen by a rock slide dam, filling the higher glacial depression of Savarenche valley (Tiberti et al., 2010). The lake free surface altitude is $2530 \mathrm{~m}$, the maximum depth is $17.1 \mathrm{~m}$, the area is $3.45 \mathrm{ha}$, the perimeter is $986 \mathrm{~m}$ and the volume is $1.611 \times 10^{-4} \mathrm{~km}^{3}$. The catchment area is 29.1 ha and is entirely dominated by acidic gneiss (Compagnoni et al., 1974); the basin is covered by debris and bare rocks $(74.8 \%)$ and by Alpine meadows (12.9\%).

Lake Trebecchi superiore fills a shallow depression produced by glacier erosion (Tiberti et al., 2010). The lake free surface altitude is $2729 \mathrm{~m}$, the maximum depth is 7.5 $\mathrm{m}$, the area is $1.42 \mathrm{ha}$, the perimeter is $565 \mathrm{~m}$ and the volume is $0.489 \times 10^{-4} \mathrm{~km}^{3}$. The catchment area is 23.7 ha and is dominated by a thick covering of calcareous schists (Compagnoni et al., 1974); the basin is covered by Alpine meadows $(77.6 \%)$ and rocks $(18.0 \%)$.

\section{Sampling and analytical methods}

\section{Sampling strategy and technique}

During the ice-free period eight samplings were performed forthnightly in NIV and TRS from July to October 2009. Each measurement was carried out from 11 a.m. to 4 p.m., close to the deepest point of the lakes, marked by a moored floating buoy. We designed a standard sampling procedure which consisted of three separate actions: i) measurement of the temperature and oxygen profiles; ii) zooplankton sampling (depth-integrated sampling); and iii) water sampling for chemical analyses (depth-integrated sampling), pico-prokaryotes (sampling at three depths) and phytoplankton (depth-integrated sampling). The collected water samples were analysed at the laboratories of the Istituto per lo studio degli ecosistemi, Consiglio Nazionale delle Ricerche (CNR ISE), Verbania Pallanza, and at the Dipartimento di Scienze della Terra e dell'Ambiente (DSTA) of the University of Pavia. 


\section{Physical and chemical parameters}

In situ temperature and oxygen profiles were obtained using a multiparametric probe, Idroprobe IP145D (IDROMAR Srl., Genova, Italy). Water samples for chemical analysis $(500 \mathrm{~mL})$ were collected with a horizontal Van Dorn bottle at $3 \mathrm{~m}$ intervals in NIV and at $2 \mathrm{~m}$ intervals in TRS at the point of maximum depth and were integrated from surface to the bottom. Water samples were stored in the dark at $4^{\circ} \mathrm{C}$ and analysed at the laboratories of CNRISE in Verbania Pallanza, following Tartari and Mosello (1997). Water samples were analysed for $\mathrm{pH}$, conductivity, alkalinity (acidimetric titration, Gran's method), total phosphorus, reactive phosphorus and reactive silica (spectrophotometry: spectrophotometer SAFAS UV mc2), major anions $\left(\mathrm{SO}_{4}{ }^{2-}, \mathrm{NO}_{3}^{-}, \mathrm{Cl}^{-}\right)$, major cations $\left(\mathrm{Ca}^{2+}, \mathrm{Mg}^{2+}, \mathrm{Na}^{+}\right.$, $\mathrm{K}^{+}, \mathrm{N}^{-\mathrm{NH}_{4}}{ }^{+}$) [ion chromatography after filtration on $0.8 \mu \mathrm{m}$ pore size filters: ion analysers Dionex series DX320 for anions and Dionex series ICS3000 for cations (Thermo Fisher Scientific Inc., Sunnyvale, CA)], total nitrogen (TN), and total organic carbon (TOC) [catalytic combustion with a Skalar Formacs series TOC/TN Analyser (Skalar, Breda, The Netherlands)]. Organic nitrogen $(\mathrm{ON})$ concentrations were calculated from the difference between $\mathrm{TN}$ and inorganic nitrogen $\left(\mathrm{IN}=\mathrm{N}^{-\mathrm{NO}_{3}-}+\mathrm{N}^{-} \mathrm{NH}_{4}^{+}\right)$concentrations.

In order to better characterise the physical and chemical properties of the lakes, we used meteorological data from the weather station of lake Serrù $\left(45^{\circ} 27,33.13^{\prime \prime}\right.$ N, $7^{\circ} 7$ '32.86" E, $2275 \mathrm{~m}$ asl) and data on precipitation chemistry from the sampling site of La Thuile $\left(45^{\circ} 43^{\prime}\right.$ $26^{\prime \prime} \mathrm{N}, 6^{\circ} 55^{\prime} 55^{\prime \prime} \mathrm{E}, 1740 \mathrm{~m}$ asl). The meteorological station of lake Serrù is located within the Gran Paradiso National Park, near the lakes under study (at $2.3 \mathrm{~km}$ from NIV and $4.5 \mathrm{~km}$ from TRS). The atmospheric deposition sampling site of La Thuile is about $30 \mathrm{~km} \mathrm{NW}$ of the lakes; 23 precipitation samples collected weekly throughout 2009 were analysed at the CNR ISE chemical laboratory following the same methods used for the lake water.

A comparison between the sum of anions and cations and between measured and calculated conductivity was performed for each analysis. Further quality-assurance measures involved the use of control charts, the analysis of synthetic samples on a regular basis and participation in inter-laboratory comparisons on rain and surface water analysis (Marchetto et al., 2010).

\section{Pico-prokaryotes}

Samples for bacteria and picocyanobacteria analysis were collected with a horizontal Van Dorn bottle at different depths: on the surface, at mid depth, and close to the bottom. To describe the dynamics of pico-prokaryotes, we frequently measured their abundance and biovolumes. The samples were kept at low temperature in $200 \mathrm{~mL}$ dark glass sterilised bottles and immediately fixed adding filtered ( 0.2 $\mu \mathrm{m})$ formalin solution ( $2 \%$ final concentration). Two subsamples (0.5-1.0 mL) were stained with 4',6-diamidino-2phenylindole (DAPI) staining (final concentration $0.1 \mu \mathrm{g}$ $\mathrm{mL}^{-1}$ ) and filtered onto black polycarbonate membranes (Millipore, $0.22 \mu \mathrm{m}$ ) (Millipore, Billerica, MA, USA). DAPI stained bacteria subsamples were enumerated under epifluorescence microscopy (filter set for Zeiss Axioplan G 365/FT395 LP 420; Carl Zeiss, Oberkochen, Germany) and picocyanobacteria were distinguished and enumerated under blue excitation, producing a specific yellow autofluorescence of autotrophic bacterial cells (filter set for Zeiss Axioplan-BP 450-490/FT 510/LP 520; Carl Zeiss). An image analysis software (Image-Pro Plus 5.1; Media $\mathrm{Cy}$ bernetics, Rockville, MD, USA) was used to distinguish between cocci and elongated bacteria (bacilli and filamentous bacteria) and to estimate their mean cell volume. The total bacterial volume was obtained multiplying total bacterial abundance by the mean bacterial biovolume weighted with the bacilli/cocci ratio. According to Posch et al. (2001), the mean cell volumes were converted into carbon biomass with the allometric relationship between cell volume (CV) and carbon content (CC), $\mathrm{CC}=218 \times \mathrm{V}^{0.86}$ (in fg cell $^{-1}$ ) (Loferer-Krößbacher et al., 1998). The total bacterial $\mathrm{CC}\left(\mathrm{mg} \mathrm{m}^{-3}\right)$ was estimated by multiplying the mean carbon biomass per cell for the bacterial density, averaged over the three sampling depths. Other methodological specifications are summarised in Straškrabová et al. (1999b).

\section{Phytoplankton}

A $500 \mathrm{~mL}$ depth-integrated sample (sampling depth at $3 \mathrm{~m}$ intervals in NIV and at $2 \mathrm{~m}$ intervals in TRS, from the surface to the bottom) was taken at the point of maximum depth with a horizontal Van Dorn bottle and stored in polyethylenterephtalate (PET) bottles. Samples were preserved by Lugol (Vollenweider, 1974) and periodically checked for colour (Lugol added if necessary). Samples were presedimented in $500 \mathrm{~mL}$ cylinders and concentrated to $1 / 10$ or $2 / 10$ of the original volume by siphoning the supernatant liquid. Counting and measuring were carried out in sedimentation chambers (Vollenweider, 1974) using an inverted microscope, equipped with phase contrast. Individual cells were counted and identified at species level, whenever possible. Cell dimensions were measured using an electronic caliper connected to a PC (Legner and Sprules, 1993) and a mean biovolume of each species was estimated from linear measures and using the closest geometrical shape (Hillebrand et al., 1999). This cell volume was the parameter used for allocating a taxon to a size class. Our size classes were defined as $\leq 0.5 \mu \mathrm{m}^{3}$, followed by $0.5-1,1-2$, $2-4 \mu^{3}$, etc., up to the largest phytoplankton cell. Phytoplankton taxa were aggregated in functional groups, following the approach proposed by Kruk et al. (2010), who outlined 7 morphologically based functional groups (MBFGs), separating the organisms according to size, pres- 
ence of flagella, mucilaginous envelope and siliceous exoskeletons. The CC of phytoplankton was estimated from biovolume $(\mathrm{BV})$ using the single conversion factor of 0.2 for all phytoplankters, $\mathrm{CC}=\mathrm{V} \times 0.2$ (Straškrabová et al., 1999b). Results are expressed as abundance (cells $\mathrm{mL}^{-1}$ ), $\mathrm{BV}\left(\mathrm{mm}^{3} \mathrm{~m}^{-3}\right)$ and organic carbon $\left(\mathrm{mg} \mathrm{m}^{-3}\right)$.

\section{Zooplankton}

Zooplankton samples were collected at the deepest point of each lake by taking vertical tows from the bottom to the surface with a conical plankton net $(40 \mathrm{~cm}$ diameter, $48 \mu \mathrm{m}$ mesh). Samples were fixed in $4 \%$ formalin directly in the field. Zooplankton was identified at species level, but coarse taxonomic levels, indicating a group of species (gr.) have been used instead of the species name for those organisms with an uncertain taxonomy (e.g., Daphnia longispina and Daphnia rosea have been lumped in the longispina group) or when the specific identification was not possible because of morphological deformations due to the preservation medium. Counting and measuring were carried out on 4-5 subsamples following Edmondson and Winberg (1971) in a closed counting chamber under a binocular dissecting microscope at 40x. Results are expressed as abundance (individuals $\mathrm{m}^{-3}$ ) and biomass ( $\mathrm{mg}$ $\mathrm{m}^{-3}$ ). For each sample, the length of up to 5000 individuals was measured with a calibrated eye-piece micrometer (Edmondson and Winberg, 1971) to obtain information on the zooplankton community size spectra. We usually estimated the size spectra for each sample by measuring the length of the first 300 organisms in the sample. However, for some samples, the number of measured individuals could vary from a few tens, in case of very low zooplankton densities, up to 5000 when rotifer species in the sample were dominant and only few individuals of the larger zooplankton species were present. In the latter case we increased the number of measured individuals in order to complete the entire size spectrum including the largest size classes. Length measurements were used to estimate the dry biomass per cubic meter for each zooplankton taxa, following the regression equations proposed by Dumont et al. (1975), Ruttner-Kolisko (1977), Shindler and Noven (1971), and Pace and Orcutt (1981). The CC of zooplankton was estimated from dry biomass (B) using a conversion factor of 0.5 for all zooplankton species, $\mathrm{CC}=\mathrm{B} \times 0.5$ (Straškrabová et al., 1999b).

\section{RESULTS}

\section{Physical and chemical properties}

The ice-free season lasted for less than 4 months in both lakes (from 5-7 July to 21-23 October in NIV and from 13 July to the end of October in TRS). An inverse thermal stratification was present in NIV at the time of the first measurement, when the lake was still partly covered with ice. From 3 August to 2 September a stable thermal stratification developed, with the depth of the thermocline increasing with time (Fig. 2). By contrast, TRS did not develop a stable thermal stratification (Fig. 2). For both lakes there was a marked cooling on 17 and 18 September, associated with a snowfall event on 16 September $(38 \mathrm{~cm}$ of snow recorded) and abundant rainfall later. This meteorological event destroyed the thermal stratification of NIV leading to a fully mixed water column.

In NIV, at the time of the first measurement, winter oxygen depletion still persisted in the deepest part of the lake, but oxygen saturation increased during the season developing a maximum immediately below the thermocline in August. Lake TRS had a constant profile of dissolved oxygen, confirming its fully mixed vertical structure (Fig. 2).

Precipitation hydrochemistry is summarised in Tab. 1 and lakes hydrochemistry is summarised in Fig. 3 and Supplementary Tab. 1. The lakes studied are not sensitive to acidification processes and atmospheric input of acid compounds (see pH, alkalinity and $\mathrm{NO}_{3}{ }^{2-}$ values, Fig. 3 ). In fact, the ionic content conductivity was low in both lakes, but TRS was characterised by a markedly higher content of calcium, magnesium and sulphate than NIV (Fig. 3). Atmospheric deposition in 2009 at La Thuile showed markedly lower average values of $\mathrm{pH}, \mathrm{SO}_{4}{ }^{2-}$, total alkalinity and conductivity with respect to lake water (Tab. 1).

Nutrient concentrations (TP, ON, $\left.\mathrm{NO}_{3}{ }^{2-}, \mathrm{TOC}\right)$ in the lakes were very low. Based on TP concentrations, NIV is oligotrophic and TRS is ultraoligotrophic. A peak in the concentration of TP was observed in NIV at the time of the first measurement $\left(20 \mu \mathrm{g} \mathrm{P} \mathrm{L}^{-1}\right)$, together with a high concentration of ammonium. Total nitrogen was partially accounted by IN: $36 \%$ (range: $24-53$ ) of TN in NIV and $38 \%$ (range: $14-73$ ) of TN in TRS. The average TN and

Tab. 1. Precipitation amount and chemical composition of the atmospheric deposition collected at the sampling station of $\mathrm{La}$ Thuile (Aosta, Italy). Chemical data are volume-weighted averages over 23 weekly samples collected in 2009.

\begin{tabular}{|c|c|}
\hline Annual precipitation (mm) & 1640 \\
\hline $\mathrm{pH}$ & 5.62 \\
\hline Alkalinity $\left(\mathrm{meq} \mathrm{L} \mathrm{L}^{-1}\right)$ & 0.03 \\
\hline Conductivity $\left(\mu \mathrm{S} \mathrm{cm}^{-1}\right)\left(20^{\circ} \mathrm{C}\right)$ & 9.36 \\
\hline $\mathrm{Ca}^{2+}\left(\mathrm{mg} \mathrm{L}^{-1}\right)$ & 0.56 \\
\hline $\mathrm{Mg}^{2+}\left(\mathrm{mg} \mathrm{L}^{-1}\right)$ & 0.05 \\
\hline $\mathrm{Na}^{+}\left(\mathrm{mg} \mathrm{L}^{-1}\right)$ & 0.30 \\
\hline $\mathrm{K}^{+}\left(\mathrm{mg} \mathrm{L}^{-1}\right)$ & 0.22 \\
\hline $\mathrm{NH}_{4}^{+}\left(\mathrm{mg} \mathrm{L}^{-1}\right)$ & 0.30 \\
\hline $\mathrm{SO}_{4}^{2-}\left(\mathrm{mg} \mathrm{L}^{-1}\right)$ & 0.63 \\
\hline $\mathrm{NO}_{3}^{-}\left(\mathrm{mg} \mathrm{L}^{-1}\right)$ & 0.25 \\
\hline $\mathrm{Cl}^{-}\left(\mathrm{mg} \mathrm{L}^{-1}\right)$ & 0.36 \\
\hline $\mathrm{TN}\left(\mathrm{mg} \mathrm{L}^{-1}\right)$ & 0.88 \\
\hline $\mathrm{ON}\left(\mathrm{mg} \mathrm{L}^{-1}\right)$ & 0.32 \\
\hline $\mathrm{DOC}\left(\mathrm{mg} \mathrm{L}^{-1}\right)$ & 1.08 \\
\hline
\end{tabular}



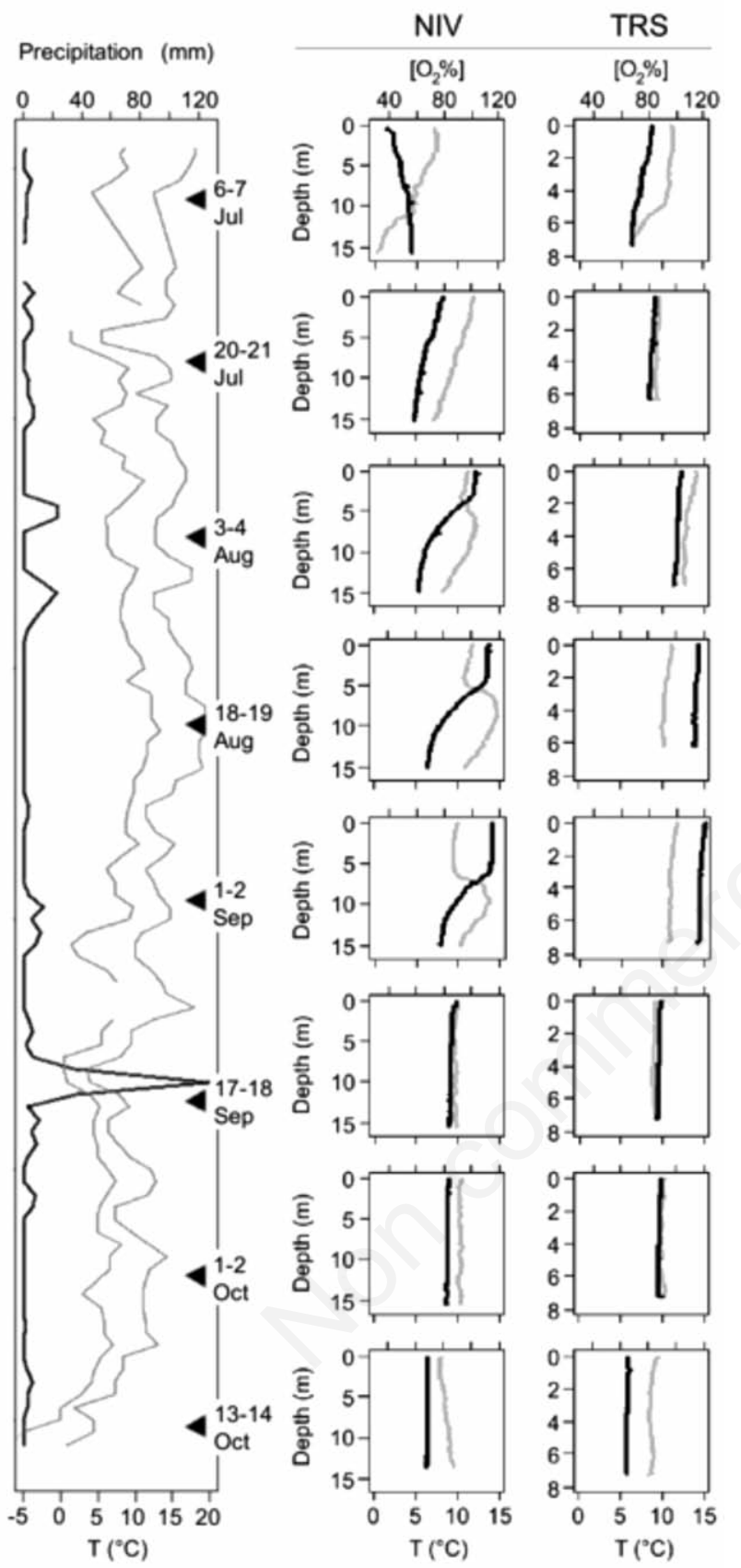

Fig. 2. Left panel: meteorological data measured at the weather station of lake Serrù $\left(45^{\circ} 27^{\prime} 33.13^{\prime \prime} \mathrm{N}, 7^{\circ} 7^{\prime}\right.$, $32.86^{\prime}$ E, $2275 \mathrm{~m}$ asl) showing daily precipitation (black line) and maximum and minimum daily temperature (grey lines) measured in the period 1 July-15 October 2009; triangles indicate the dates of the measurements in lake Nivolet superiore (NIV) and Trebecchi superiore (TRS) (Gran Paradiso National Park). Right panels: temperature (black) and dissolved oxygen (grey) profiles in NIV and TRS for each measurement date.
IN concentrations in the atmospheric deposition in 2009 were higher than in the lakes (Tab. 1) and IN in atmospheric deposition accounted for $62.5 \%$ of TN. Mean TN:TP ratios were 25 (range: $11-32$ ) in NIV and 35 (range: 26-110) in TRS, corresponding to a mean molar ratio of 56 (range: 24-70) in NIV and 78 (range: 58-244) in TRS. Silicon is a nutrient for diatom algae and its concentration was higher in TRS than in NIV; after the peak at the beginning of the sampling period, silicon values decreased in both lakes.

\section{Pico-prokaryotes}

Pico-prokaryotes were composed of bacteria (we did not differentiate between Bacteria and Archaea) and picocyanobacteria. Bacteria abundance differs in the two lakes, reaching almost $3 \times 10^{6}$ cells $\mathrm{mL}^{-1}$ in NIV and $1.3 \times 10^{6}$ cells $\mathrm{mL}^{-1}$ in TRS (Fig. 4; Supplementary Tab. 1). Conversely, their fluctuations during the season were very similar, showing a peak of abundance at the end of August. In NIV the highest numbers have been found near the bottom, whereas homogeneous densities were recorded in the water column of TRS. Immediately after melting (in July) the bacteria number was high in deeper layers, but decreased abruptly in the following two weeks. This pattern is even more evident looking at the biovolume data, particularly in NIV. The mean cell biovolumes were similar in the two lakes, ranging from 0.1 to $0.3 \mu \mathrm{m}^{3}$ cell $^{-1}$. Larger cells were found near the bottom in NIV and in the middle of the water column in TRS. Smaller cells were recorded at the peak of abundance during late summer.

Picocyanobacteria abundance markedly differed in the two lakes (data reported in Supplementary Tab. 1), with an higher peak in NIV $\left(61 \times 10^{3}\right.$ cells $\mathrm{mL}^{-1}$, August 3$)$ than in TRS $\left(4.6 \times 10^{3}\right.$ cells $\mathrm{mL}^{-1}$, July 7$)$. As a general spatial pattern, their number increased near the bottom and was very low near the surface.

\section{Phytoplankton}

Looking at the seasonal dynamics (Fig. 5), a bimodal pattern is evident for both lakes, with the first peak immediately after the disappearance of the ice cover and the second one occurring at the end of the summer period. In terms of densities, for NIV the first peak is lower than the second. However, in terms of biomass the opposite is true (Fig. 5). This is due to the fact that the second bloom is mainly due to flagellates, while in the first bloom some large diatoms have also been detected. In TRS there are three distinct peaks of abundance, whereas a bimodal pattern is visible in the biomass record. Concerning the biovolume variability of the whole phytoplankton assemblages, NIV showed higher fluctuations, both between and within samples. The common occurrence, in NIV samples, of taxa belonging to different size classes explains a higher variability of the bio- 
volume range recorded in this lake. A raw comparison between the two lakes seems to suggest slightly lower average cell sizes in TRS: this is mainly due to the dominance in NIV of some large taxa, such as Peridinium spp., Cryptomonas spp. and Surirella sp., absent in TRS.

Fig. 6 shows the seasonal changes of phytoplankton in terms of MBFG. Starting from biomass data, the summer samples in NIV were dominated by groups V (unicellular flagellates of medium to large size) and VI (all diatom taxa), whereas, in TRS, groups VI was dominant. Autumn samples were characterised by groups VII (large mucilaginous colonies, in this case the chlorophyte Willea irregularis Schmidle) and VI in NIV and by groups V (including Cryp- tomonas spp. and Plagioselmis nannoplanctica Skuja) and VI in TRS. Considering the abundance of data, the role of smaller taxa is emphasised in summer samples: groups I (small organisms with high surface-to-volume ratio, mainly Pseudanabaena sp. in this case) and II (small chrysophytes) are the most important in NIV, whereas in TRS group II is clearly dominant (with Kephyrion sp. and Chromulina sp.), followed by group VI (small Cyclotella spp.). In autumn samples, smaller taxa declined: in NIV, group VII and the medium sized group IV are dominating, due to Willea irregularis, together with Aphanocapsa sp. and Sphaerocystis schroeterii Chodat. In TRS, group V was the dominant in September and October (mainly Plagioselmis nannoplanc-
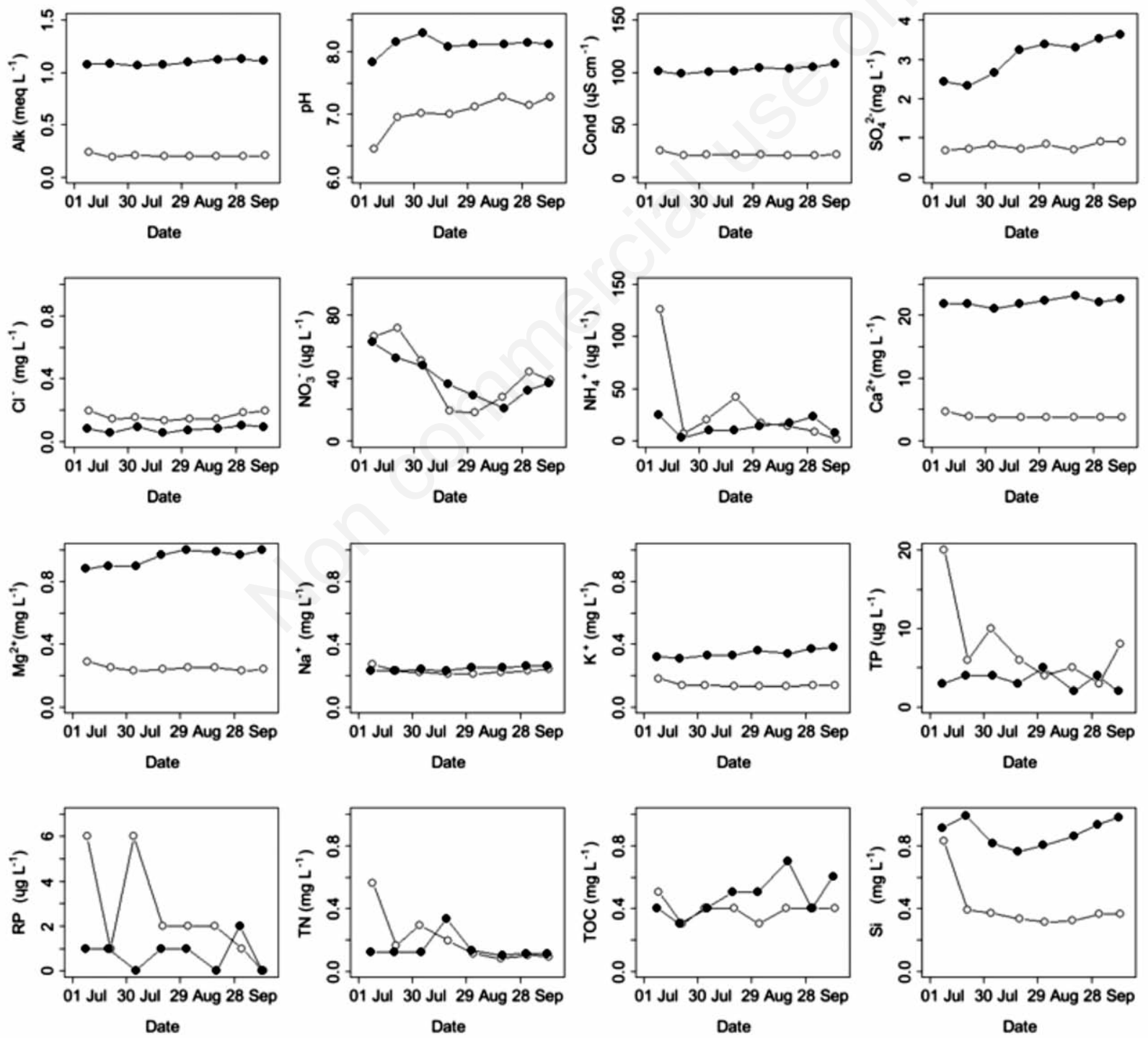

Fig. 3. Summer dynamics of the main chemical variables in lakes Nivolet superiore (NIV) and Trebecchi superiore (TRS) (Gran Paradiso National Park). Open circles refer to NIV and black circles to TRS. 
tica), together with group VI. Comparing the two lakes, a different pattern emerged in summer-to-autumn transition: in NIV a shift from flagellates (both small and large) to colonial and mucilaginous forms occurred, while in TRS the flagellates always dominated, with smaller ones (group II) most important in summer and larger ones (group V) most important in autumn. The dynamic of diatoms, though always being important in both lakes in terms of biomass and sometimes abundance in TRS, did not show a clear seasonality. However, we should consider that their presence in the pelagic samples could be reasonably due to a recruitment from the bottom of the lakes, due to re-suspension.

\section{Zooplankton}

The zooplankton communities consisted of rotifers, copepods and cladocerans. A complete list of the species with their densities is reported in Supplementary Tab. 1. Ten different zooplankton taxa were recorded in NIV and 13 in TRS. The composition of the zooplankton communities was very similar in both lakes, sharing the same dominant species. The most common Crustaceans were Arctodiaptomus alpinus Imhof, Cyclops gr. abyssorum Sars and Daphnia gr. longispina Müller, which were found in all 8 samples in both lakes. The crustacean community was completed by Eucyclops serrulatus Fisher (both in NIV and TRS), Daphnia gr. pulicaria Forbes (both in NIV and TRS, previously considered as Alpine populations of Daphnia middendorffiana Fisher; Tiberti, 2011), Alona quadrangularis Müller (only in TRS) and Chydorus sphaericus Müller (only in TRS). Concerning the rotifer community, Keratella quadrata Müller was by far the most common species in both lakes.

Fig. 7 describes the zooplankton dynamics in NIV and TRS, which showed the same patterns in the two lakes. Lake Trebecchi superiore supported higher zooplankton densities and biomass than NIV. The total number of individuals per cubic meter showed two peaks, the first one being determined by rotifers at the beginning of the summer and the second mainly determined by Daphnia gr. longispina in September. The peak of copepods was observed slightly earlier than that of cladocera. On the contrary, there was only one peak of zooplankton biomass in September, which was sustained mainly by crustaceans, since the contribution of rotifers to the total biomass was always very small. The size spectra of the zooplankton community grew in the course of summer and reached relatively stable values in midsummer.
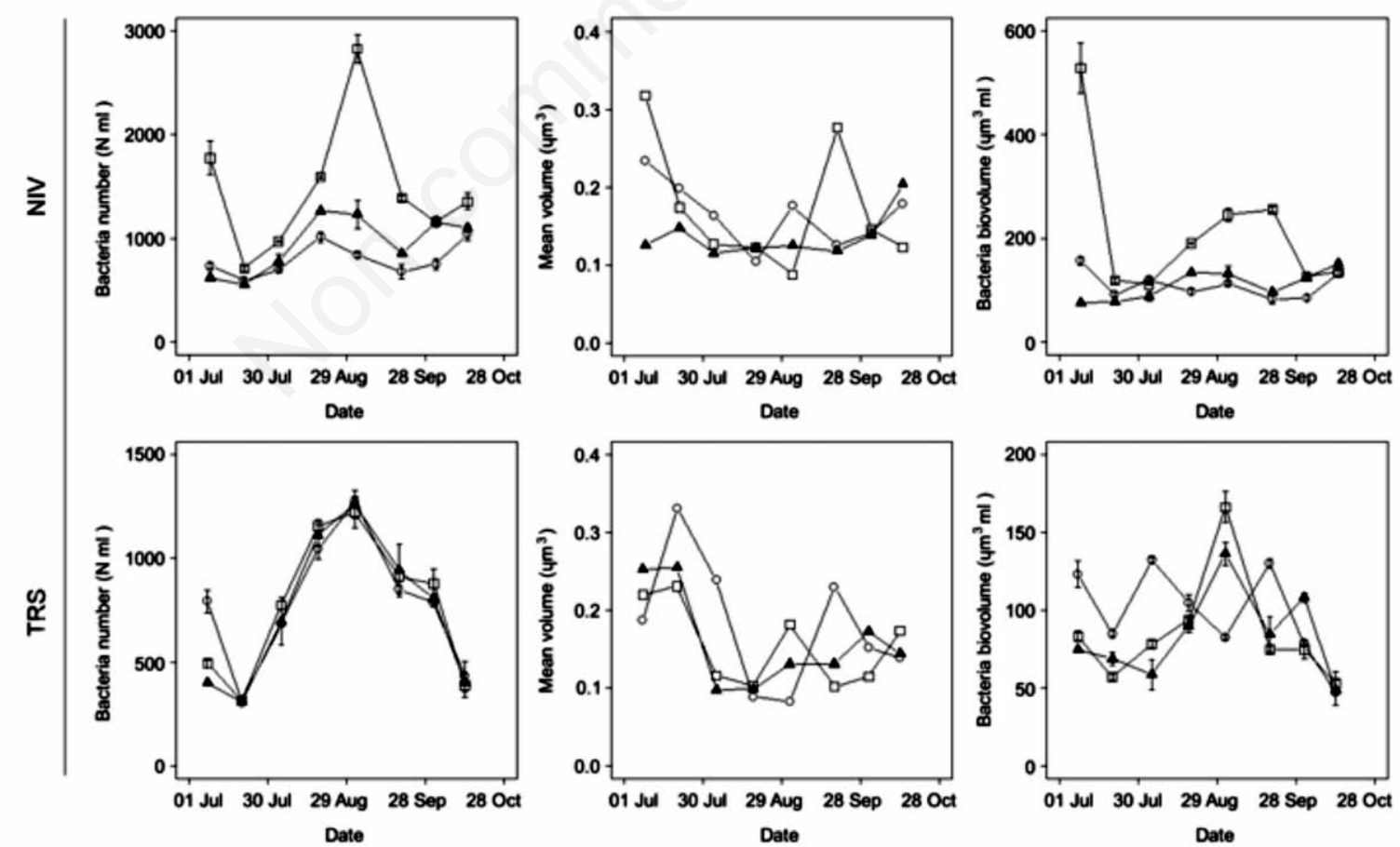

Fig. 4. Dynamics of the abundances $[ \pm 1$ standard error (se)], mean cell volumes and total biovolumes $( \pm 1 \mathrm{se})$ of the bacterial community at three sampling depths in lakes Nivolet superiore (NIV) and Trebecchi superiore (TRS) (Gran Paradiso National Park). Open circles refer to surface samples, black triangles to samples collected in the middle of the water column $(8.5 \mathrm{~m}$ in NIV and $3.7 \mathrm{~m}$ in TRS) and open squares to samples collected close to the bottom (15.5-16.5 $\mathrm{m}$ in NIV and 7.0-7.2 in TRS). 
Detailed ecological dynamics could be described only for the most common zooplankton species. Cyclops gr. abyssorum reached its maximum density at the end of August (Supplementary Tab. 1). The population at the beginning of the summer was mainly composed by nauplii and copepodids, but some large overwintering reproductive stages, including some adult males and egg-carrying females, were still present in both lakes. The reproductive stages disappeared from the second sampling (20-21 July) and reappeared from mid-August until October in NIV and just in mid-August in TRS. Naupliar stages of Cyclops were found during the whole measurement period. Arctodiaptomus alpinus reached its maximum density on 4 August in TRS and on 2 September in NIV (Supplementary Tab. 1). On the first sampling date, the population was composed exclusively of nauplii, which tended to completely disappear later in the season. The reproductive stages of Arctodiaptomus alpinus were found from the beginning of August till the end of the summer, both in NIV and TRS. Daphnia gr. longispina reached its maximum density on 17
September in NIV and on 1 October in TRS (Supplementary Tab. 1). At the beginning of summer there were only small individuals, while the first reproductive stages were found starting from August, both in NIV and TRS. On 17 and 18 September there were the first cases of resting eggs (ephippia) production, which continued and intensified until the end of summer. Daphnia gr. pulicaria was found at low density levels, reaching higher densities in late August and early September (Supplementary Tab. 1). No males have been found during the sampling campaign, in agreement with the hypothesis that those populations are obligatory parthenogenetic (Tiberti, 2011). Interestingly, both Daphnia gr. longispina and Daphnia gr. pulicaria showed a dark cuticular pigmentation. Concerning rotifer species, the dynamics of Keratella quadrata is substantially the same as the dynamics of the entire rotifer community, reaching its maximum density and biomass at the first sampling date (Supplementary Tab. 1). Polyarthra gr. dolichoptera Ehrenberg appeared at the end of the season, only in NIV (Supplementary Tab. 1).
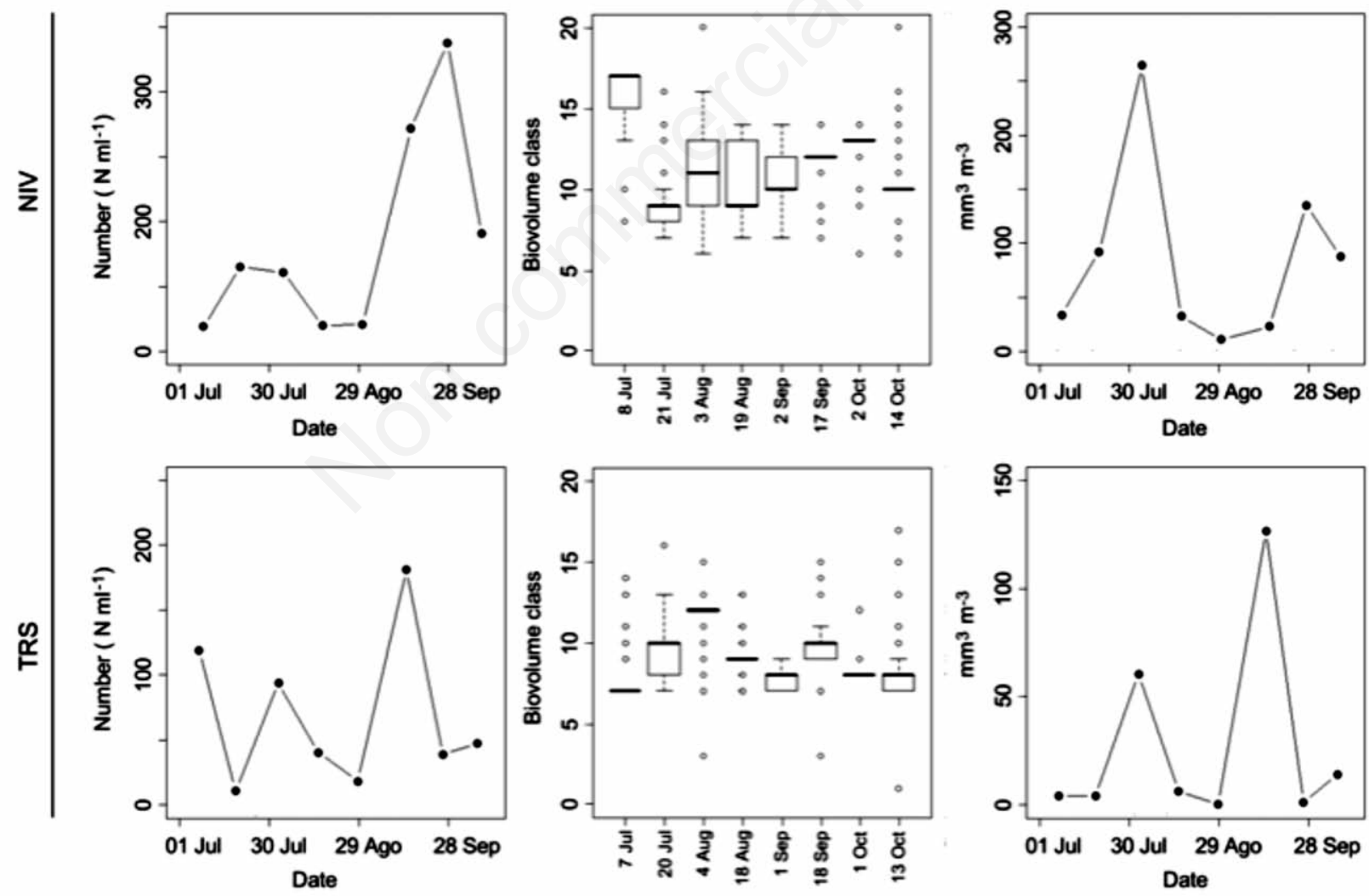

Fig. 5. Phytoplankton community dynamics within the lakes Nivolet superiore (NIV) and Trebecchi superiore (TRS) (Gran Paradiso National Park). Left panels: phyplankton densities. Centre panels: size variation within the phytoplankton community based on 20 size classes; the box-plots show the median and the $1^{\text {st }}$ and $3^{\text {rd }}$ quartiles; notches indicate \pm 1.58 multiplied by the interquartile range and divided by the square root of the total number of measured specimens; empty circles are outliers. Right panels: phytoplankton biomass. 


\section{DISCUSSION}

\section{Hydrochemical characteristics}

The ecosystems studied are naturally oligotrophic or ultraoligotrophic and, according to the Redfield's ratio, the high TN:TP molar ratios suggest phosphorus limitation of the algal growth (O'Sullivan and Reynolds, 2004). During summer 2009, excluding the unusually high TP concentration at the time of the first measurement in NIV, we could not find phosphorus or nutrient input events due to pasture, tourism or other human activities and we can reasonably exclude anthropogenic nutrient enrichment. The phosphorus peak observed in NIV during the first measurement could be explained by a release from the sediment owing to the anoxia of the deeper layers, as demonstrated by the oxygen profile and by the typical smell of the water. As observed by Ohlendorf et al. (2000), Alpine lakes can be naturally affected by anoxic
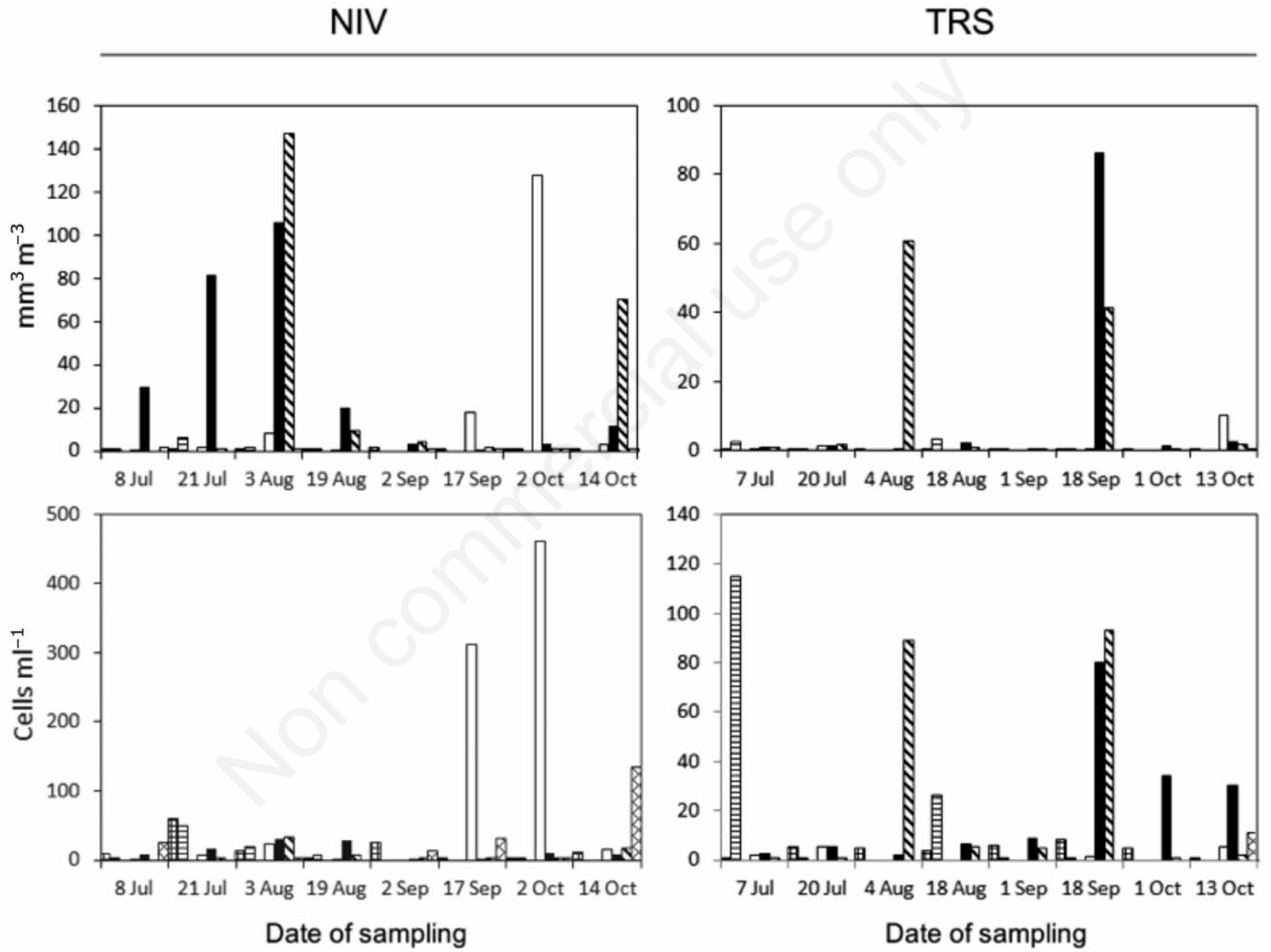

Date of sampling

TRS

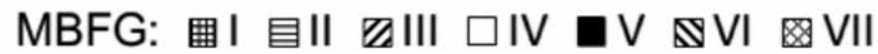

Fig. 6. Seasonal fluctuations of the phytoplanktonic morphologically-based functional groups (MBFG; Kruk et al., 2010) within lakes Nivolet superiore (NIV) and Trebecchi superiore (TRS) (Gran Paradiso National Park): abundance data in the upper panels, biomass data in the lower ones. Group I: small organisms with high surface:volume ratio (Chlorococcales, Chroococcales, Oscillatoriales, Xanthophyceae, Ulothricales); Group II: small flagellated organisms with siliceous exoskeletal structures (Chrysophyceae); Group III: large filaments with aerotopes (Nostocales, Oscillatoriales); Group IV: organisms of medium size lacking specialized traits (Chlorococcales, Oscillatoriales, Xanthophyceae, Zygnematophyceae); Group V: unicellular flagellates of medium to large size (Cryptophyceae, Dinophyceae, Euglenophyceae, Volvocales, Chlorococcales); Group VI: non-flagellated organisms with siliceous exoskeletons (Bacillariophyceae); Group VII: Large mucilaginous colonies (Chlorococcales, Chroococcales, Oscillatoriales). 
conditions at the sediment-water interface during winter ice-covered conditions and particularly during thawing. Bottom oxygen depletion usually persists until the lake is completely ice-free and, subsequently, oxygen undergoes a rapid increase. In the absence of inputs of glacial silt, the scarcity of nutrients allows for very transparent waters: in Alpine lakes most of the organic carbon is dissolved and TOC concentration is a good indicator of water transparency to visible and UV radiations (Tiberti and Iacobuzio, 2013). The measured low values of TOC indicate that the lakes under study are naturally transparent, as also demonstrated by the dark pigmentation of both Daphnia gr. longispina and Daphnia gr. pulicaria, which are known to develop cuticolar pigmentation as a defence against UV radiations (Hansson and Hylander, 2009).

Both NIV and TRS show a clear connection between lithology of the watershed and lake hydrochemistry. The basin of TRS is dominated by highly soluble calcareous schists (Compagnoni et al., 1974), which through weathering processes, markedly increase $\mathrm{pH}$ and alkalinity. Conversely, NIV, whose basin is totally dominated by insoluble acidic gneiss, has a low weathering rate. However, despite the composition of its watershed, according to Turner et al. (1986) and Mills and Schindler (1986) NIV is not affected by acidification, as demonstrated by $\mathrm{pH}$ and alkalinity with minimum values of 6.45 and $196 \mu$ eq $\mathrm{L}^{-1}$, respectively.

Ion composition of both lakes is also influenced by the inputs from the basin: calcium and bicarbonate from weathering processes were always the prevailing ions, followed by $\mathrm{SO}_{4}{ }^{2-}, \mathrm{Mg}^{2+}$ and $\mathrm{Na}^{+}$(in NIV) or $\mathrm{K}^{+}$(in TRS). The $\mathrm{SO}_{4}{ }^{2-}$ to $\mathrm{Cl}^{-}$ratio in lake water (3.6-5.9 in NIV, 29.664.8 in TRS) proved to be markedly higher than the corresponding ratio in seawater $(0.103)$.

High $\mathrm{SO}_{4}{ }^{2-}$ concentrations in lake water can be a symptom of long-range transport of air-born pollutants. This is not the case for NIV and TRS, as the content of sulphate in atmospheric depositions (Tab. 1) was markedly lower than in lakes. As a consequence, the $\mathrm{SO}_{4}{ }^{2-}$ content in lake water can be largely attributed to weathering of rocks and soils bearing sulphur minerals. This was confirmed also by higher concentrations of $\mathrm{SO}_{4}{ }^{2-}$ in TRS, whose catchment is formed by more soluble rocks with respect to NIV. Also, the $\mathrm{Na}^{+}$to $\mathrm{Cl}^{-}$ratio in lake water (2.65-4.60 in TRS, 1.26-1.64 in NIV) was above the ratio in marine water $(0.86)$ and in precipitations at La Thuile (0.82), indicating a weathering contribution to $\mathrm{Na}^{+}$concentration (Rogora et al., 2008).

Concentrations of nitrogen $(\mathrm{N})$ compounds can be used as an index of the impact of human settlement on remote lakes: when lakes are subject to low $\mathrm{N}$ input $(<1 \mathrm{~kg}$ $\mathrm{N} \mathrm{ha}^{-1} \mathrm{y}^{-1}$ ), nitrate $\left(\mathrm{NO}^{3-}\right)$ concentrations are usually low and $\mathrm{ON}$ accounts for a substantial proportion of TN (Hedin et al., 1995; Kaushal and Lewis, 2003; Rogora et al., 2008). Long-range transport of $\mathrm{N}$ compounds from intensively cultivated or industrial regions affect lakes in different remote areas of Europe (Allott et al., 1995; Kopàček et al., 2001; Evans et al., 2001; Wright et al., 2005). Lake Nivolet superiore and TRS could be threatened by the proximity of the Po plain (Northern Italy), one of the most densely populated and industrialised regions in Europe. Indeed, the areas surrounding the Alpine rim produce nitrogen deposition among the highest in Europe (Rogora et al., 2001) and, in 2009, the total $\mathrm{N}$ concentration $\left(0.88 \mathrm{mg} \mathrm{L}^{-1}\right)$ and deposition rates $(14.4 \mathrm{~kg} \mathrm{~N}$ $\mathrm{ha}^{-1} \mathrm{y}^{-1}$, calculated by annual precipitation and average $\mathrm{N}$ content) at the sampling station of La Thuile were high and similar to those usually reported for the Alpine range ( $\mathrm{N}$ deposition rate: $14-15 \mathrm{~kg} \mathrm{~N} \mathrm{ha}^{-1} \mathrm{y}^{-1}$; Rogora et al., 2006). However, the final nitrogen concentration in the lakes depends on retention process (closely related to vegetation and catchment characteristics) (Marchetto et al., 1995; Rzychon and Worsztynowicz, 2008), in addition to $\mathrm{N}$ deposition rate. Inorganic nitrogen concentration in the lakes studied $\left(0.07 \mathrm{mg} \mathrm{N} \mathrm{L}^{-1}\right.$ in NIV, and $0.04 \mathrm{mg} \mathrm{N} \mathrm{L}^{-1}$ in TRS) was considerably lower than the values found in other lakes in the Gran Paradiso National Park $(0.17 \mathrm{mg}$ $\mathrm{L}^{-1}$, average IN concentration from a set of 15 Alpine lakes sampled in 2009, unpublished data) and for the Alps (0.8-1.0 $\left.\mathrm{mg} \mathrm{L}^{-1}\right)$ (Rogora et al., 2003, 2008), and it was comparable with the values from European and non-European pristine areas subject to low atmospheric input of $\mathrm{N}$ compounds (Boavida and Gliwicz, 1996; Tartari et al., 1998; Murphy et al., 2010). Moreover, the dominance of $\mathrm{ON}$ on IN suggests that retention processes at these sites were able to mitigate the effects of the high $\mathrm{N}$ deposition. This is not necessarily an indication that a weak impact of long range pollutants and some confirmatory measurements (e.g., trace metals and organochlorine compounds concentrations) would be required, but the lakes studied are probably less affected by $\mathrm{N}$ and deposition of pollutants than other Alpine lakes (Tiberti et al., 2010), possibly due to a higher retention capacity and to a lower amount of precipitation in the Gran Paradiso National Park area (Frei and Schär, 1998).

\section{Trophic compartements in Alpine lakes}

The lakes under study are exposed to extreme climatic conditions causing a short ice-free season and rapid changes in their physical properties. Temperature profiles change under the influence of seasonal, geographic, morphometric and climatic factors: despite its higher altitude, owing to its better exposition and its moderate depth, TRS showed a polymictic regime and was slightly warmer than NIV, which instead showed a clear dimictic regime. Dissolved oxygen profiles are strongly influenced by thermal stratification. Except for the first sampling date, TRS always showed a constant oxygenation along the water col- 
umn, confirming its fully mixed vertical structure. At the beginning of the ice-free season (on 8 July), the winter oxygen depletion still persisted at the bottom of NIV and a maximum of oxygen, immediately below the thermocline, was present during the summer stratification (from 3 August to 2 September). It is well known that the thermocline acts as a barrier for vertical algal movements, resulting in high algal densities and correspondingly high oxygen production (Hansson, 1996).

Looking at the pico-prokaryote abundance, the two lakes showed a similar seasonal distribution of bacterial numbers, with a very clear bell-shaped pattern peaking at the end of August, but different densities. In NIV, the number of bacteria was higher in comparison to other Alpine lakes and to TRS, possibly due to different RP concentrations and to a greater depth of NIV, which could offer more hospitable ecological niches. In lake Paione superiore (Central Italian Alps), the range of bacteria abundance was $0.1-1 \times 10^{6}$ cells $\mathrm{mL}^{-1}$ (Callieri and Bertoni,

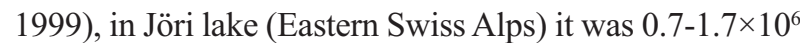
cells $\mathrm{mL}^{-1}$ (Hinder et al., 1999), and in Gossenköllesee (Tyrol, Austria) it was even lower $\left(2.5-5.5 \times 10^{5}\right.$ cells $\left.\mathrm{mL}^{-1}\right)$ (Wille et al., 1999).

In both lakes, the bacterial density reached its maximum between the two peaks of phytoplankton and zooplankton in a period of P-limitation. Bacteria are known to outcompete phytoplankton for P (Vadstein, 2000) and could have taken advantage from the organic carbon excretion during the first phytoplankton peak and the subsequent cellular degradation during the population decrease (Callieri et al., 2006). At the beginning of the season, NIV showed a high peak of bacterial numbers and biomass, in correspondence with the TP and RP peaks, near the bottom. This could be due to anaerobic ammonium-oxidising (anammox) bacteria, which are mainly Planktomycetes and able to grow anaerobically oxidising ammonia (Madigan et al., 2009). Near the bottom of NIV, we found oxygen depletion and an ammonia peak; these
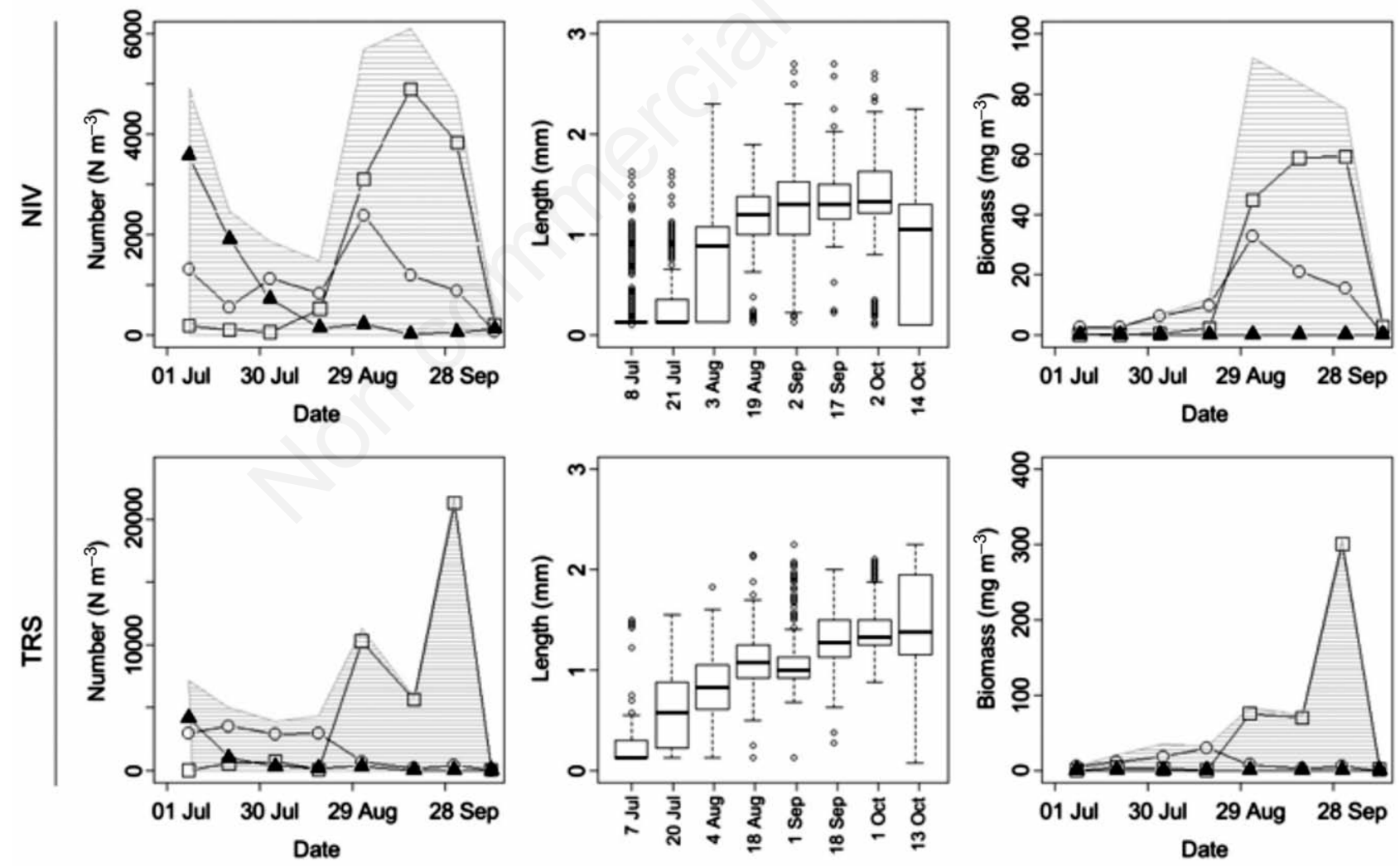

Fig. 7. Zooplankton community dynamics within the lakes Nivolet superiore (NIV) and Trebecchi superiore (TRS) (Gran Paradiso National Park). Left panels: zooplankton densities. Centre panels: community size spectra; the box-plots show the median and the $1^{\text {st }}$ and $3^{\text {rd }}$ quartiles; notches indicate \pm 1.58 multiplied by the interquartile range and divided by the square root of the total number of measured specimens; open circles are outliers. Right panels: zooplankton biomass. Shaded areas: total density (left panels) or biomass (right panels); black triangles: rotifers; open circles: copepods; open squares: cladocerans. 
conditions strengthen the hypothesis of Planktomycetes (large bacteria) which are likely to occur in marine and freshwater habitats.

As for the bacterial size, we noted larger cells at the beginning of the ice-free period at low grazing pressure, when zooplankton and flagellates were low. The mean cell size decreased later in the season, in correspondence to the increase of larger cell consumers. We cannot exclude that the peak of larger cells on 17 September was spurious and related to a strong precipitation event, registered just before that date, and the subsequent runoff carrying terrestrial bacterial species into the lakes.

The other component of pico-prokaryotes, the picocyanobacteria, in general are of low importance in high altitude lakes for their vulnerability to UVR and photosynthetic active radiations (PAR) of high intensity (Callieri et al., 2001). Nevertheless, they were numerous in NIV, near the bottom, as compared with other Alpine lakes (Callieri and Bertoni, 1999; Wille et al., 1999). This result could be explained by the neutral $\mathrm{pH}$ of NIV and by the maximum depth of the lakes, which constitutes in itself a potential refuge from harmful radiation.

Owing to the scarcity of nutrients (especially phosphorus) we may expect phytoplankton to be dominated by species with small cell dimensions allowing for a higher surface:volume ratio and therefore for a more efficient nutrient uptake (Callieri et al., 2006). Indeed, the measurements indicated that phytoplankton community in NIV and TRS was commonly dominated by flagellates (chrysophytes, dinoflagellates, and cryptophytes), as generally reported for European Alpine lakes (Goldman and Home, 1983; Tolotti et al., 2006). Flagellates are usually more resistant to harsh winter conditions typical of high mountain lakes than other phytoplankters, and they are able to thrive under ice and form inocula, giving rise to the spring growing phase soon after ice melting (Reynolds, 2006).

The summer algal succession was similar in both NIV and TRS. During the few months of the high-altitude icefree season, three periods were evident: i) a spring development, during snowmelt, ii) a midsummer period of minimal algal abundance, and iii) a fall growth. This double-peak structure is common in Alpine lakes (Mcknight et al., 1990; Winder et al., 2003).

In wintertime, the primary production of Alpine lakes is constrained by abiotic conditions, such as low temperature and light scarcity, owing to the formation of a thick ice cover (Mcknight et al., 1990). Only with ice thawing and with the rapid nutrient flushing during snowmelt, algae can develop (Straile, 2005; Rott, 1988) and produce the first seasonal peak. The spring algal bloom is considered to sustain the growth of zooplankton herbivores, which often control algae, reducing their density within the so called clear water phase (Lampert et al., 1986). The same ecological mechanism could have produced the mid-summer collapse of phytoplankton observed in NIV and TRS. The second algal blooms developed when zooplankton communities were still increasing in biomass and abundance and, at this phase, the zooplankton grazing was unable to control the phytoplankton community. As a consequence, phytoplankton shifted its taxonomic composition towards less edible taxa such as mucilaginous colonies in NIV and the medium sized flagellates in TRS. The decrease of temperatures, affecting the rates of zooplankton grazing (Vidal, 1980) is a further factor contributing to the decrease of predation pressure. At the end of summer, abiotic conditions returned to play a major role in shaping algal dynamics and the entire system plunged again towards winter conditions.

Excluding diatoms, whose dynamics was not clear and could have been affected by re-suspension from the bottom, the phytoplankton dynamics and assemblages were similar in the two lakes. The presence in NIV of poor Pcompetitors such as Gymnodinium sp. and Peridinium sp. (group V), on the other hand, could indicate a less severe nutrient limitation in this lake, while group II chrysophytes in TRS indicated permanent low-nutrient conditions (Kruk et al., 2010). In this respect, the higher nutrient availability in NIV could support larger-sized flagellates (Litchman and Klausmeier, 2008) and, later, the observed development of little edible (Reynolds, 2007) mucilaginous colonies (group VII).

The zooplankton dynamics was almost identical in TRS and NIV, showing a transition from a community dominated by small zooplankters to a community where large particle-feeders (e.g., Daphnia sp.) were dominant. The zooplankton ecological succession showed a few distinct stages: i) Early zooplankton community. Immediately after ice melting, rotifers dominated, while the crustacean community was composed of larval and juvenile stages. At this stage, the size spectrum of the entire zooplankton community was at its seasonal minimum. ii) Transition zooplankton community. In early summer (July) rotifers declined while crustaceans grew in number and size. The total number of individuals decreased owing to the decline of rotifers, but the total biomass showed a small increase and the community size spectrum increased. iii) Maturity zooplankton community. This stage was dominated by large crustacean species with the seasonal peaks of copepods and Daphnids. A strong increase of number and biomass of zooplankton was coupled with the highest community size spectrum. iv) Senescence zooplankton community. At this stage the zooplankton community collapsed, with a reversal of the seasonal patterns of biomass and number of individuals.

Biotic interactions among zooplankton species seemed to play a key role in determining the seasonal dynamics. Predation by Cyclops (Brandl, 1998, 2005) and competition with large grazers (e.g., Daphnia sp.; Eby et 
al., 2006) could explain the observed rotifer decline between stages i) and ii) and the fast-paced dynamics of stage iii) (Manca and Comoli, 1999). In general, during the short Alpine summer different zooplankton taxa succeeded one another and completed their life cycle before the end of the ice-free season, without a clear stationary phase in the zooplankton succession.

Occasionally, other species, usually inhabiting the littoral zone (Eucyclops serrulatus, Alona quadrangularis and Chydorus sphaericus) were also found in pelagic samples, probably as a result of the action of wind or of a seasonal increase of their densities, but their contribution to the community biomass was always very small.

\section{Non-stationary dynamics of Alpine lakes}

Some differences were detected in the ecological dynamics of NIV and TRS, which can probably be ascribed to the natural variability among ecosystems or to the different morphology and hydrochemistry of NIV and TRS. However, the similarities between the two ecosystems remain strong and some of the observed processes are almost identical in NIV and TRS.

In Fig. 8 we summarise the summer succession of the two lakes from ice melting to water cooling in autumn.

Initial stage. At the beginning of summer, ice breakup and snowmelt cause a sudden shift from light-limited conditions to high light intensity and a large flushing rate of terrestrial nutrients. Bacteria dominate the plankton community, while the primary production is low and still af- fected by the winter ice cover. The zooplankton community is at its seasonal minimum and is dominated by rotifers and larval stages of crustaceans, with a few large, overwintering cyclopoids and daphnids carrying eggs.

Early plankton community. Owing to nutrient availability, phytoplankton reaches its first peak at the expenses of bacteria, while there is a transition from rotifer to crustacean dominance in the zooplankton community.

Clear water phase. Phytoplankton declines and bacteria return to dominate the plankton community. Zooplankton is still in transition.

Late plankton community. Owing to the increase of zooplankton density and biomass and the two consecutive peaks of copepods and daphnids, the total CC of the plankton community increases. Phytoplankton reaches a second peak, shifting its taxonomic composition towards less edible taxa, and bacteria reach the maximum seasonal density and begin to decline.

Plankton community senescence. The rapid water cooling puts an end to the summer succession, with the zooplankton community collapsing and the bacteria becoming dominant.

The first and the last stages of the ecological succession were strongly affected by climatic conditions, while in the middle of summer, when climatic conditions became less extreme, the community succession was increasingly determined by internal dynamics (e.g., competition and predation).

There are some clear similarities between this successional scheme and the PEG (plankton ecology group)
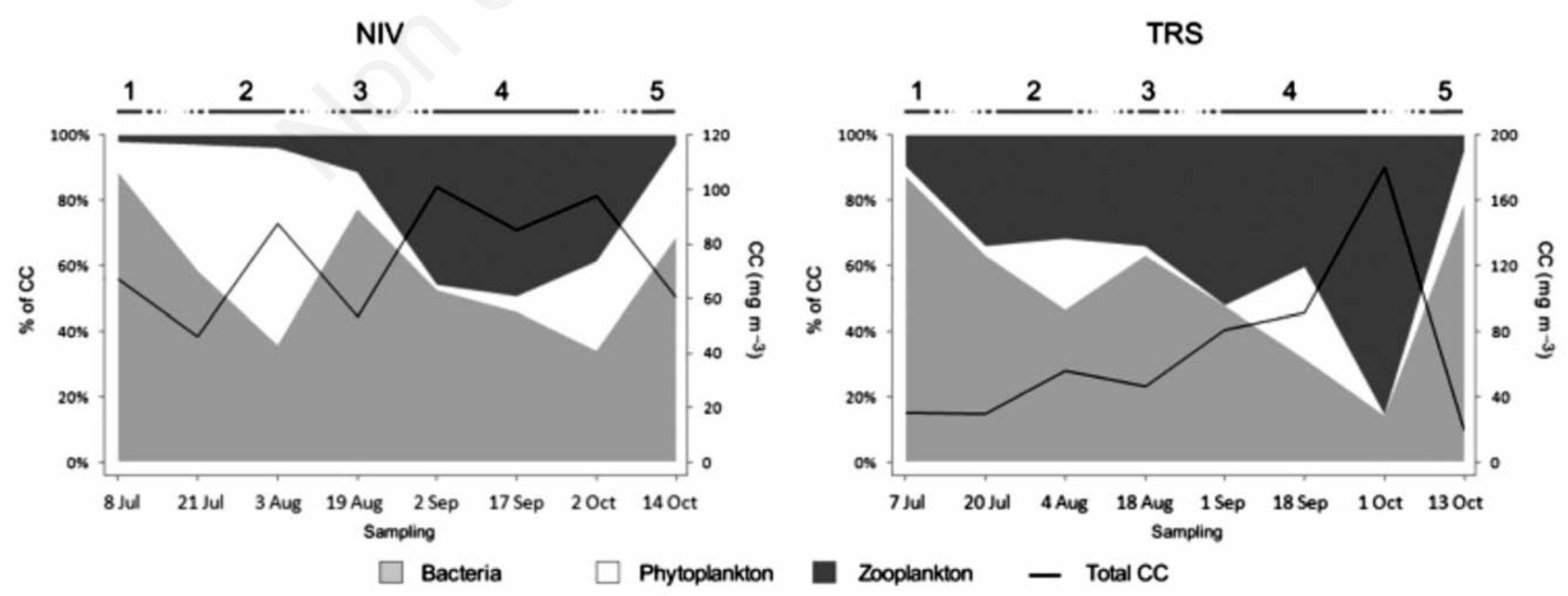

Fig. 8. Percentage partitioning of organic carbon within the plankton community (primary axis), total carbon content (CC) within the plankton community (secondary axis) and partitioning of the summer dynamics into 5 successional stages. 1 , initial stage; 2, early plankton community; 3, clear water phase; 4, late plankton community; 5, plankton community senescence. Data collected during the 2009 ice-free summer season in two Alpine lakes, Nivolet superiore (NIV) and Trebecchi superiore (TRS) in Gran Paradiso National Park (western Italian Alps). 
model (Sommer et al., 1986), which describes the idealised plankton succession in a typical temperate lake. Since its publication, numerous cases showing that this model is not universally applicable and omits some important ecological processes have been put forward (e.g., bacterial loop; O'Sullivan and Reynolds, 2004). Nevertheless, the model provides a coherent conceptual framework for the interpretation of plankton succession, which can be interestingly compared with the observed dynamics. The PEG model refers to warmer lakes where ice-free seasons are longer than in Alpine lakes and fish are naturally present. The turnover of the crustacean zooplankton species usually observed in temperate lakes is time-limited in Alpine lakes, where large crustaceans have enough time just for one generation and are not affected by fish predation. If we could imagine to condense the PEG model in a shorter ice-free season and to remove from the model the effect of fish, it is likely to provide something very similar to the summer succession of NIV and TRS. However, further efforts and intercomparisons are needed to understand how the successional scheme described for NIV and TRS can be applicable to other Alpine lakes and to include the winter, under-ice dynamics.

\section{CONCLUSIONS}

The ecological dynamics of NIV and TRS show very clear initial and final stages, corresponding to ice breakup at the beginning of July and water cooling at the end of summer, respectively. Allogenic environmental fluctuations, together with the short duration of the Alpine summer, are responsible for the fast-paced ecological dynamics observed in the two lakes, which never reach a stationary equilibrium, intended here as a period of little variability of total biomass and community composition (Naselli-Flores et al., 2003).

The rapid succession of events in extreme ecosystems, such as the Alpine lakes studied here, confirm the complexity of the interactions among the different trophic compartments, as well as the important role of external environmental factors. This research underlines the ecological value of seasonal niche partitioning among organisms with different size. In addition, prokaryotes contribute efficiently to the TOC in periods of nutrient limitation or oxygen depletion.

\section{ACKNOWLEDGMENTS}

The authors would like to thank Bruno Bassano, Achaz von Hardenberg (Gran Paradiso National Park) and Giuseppe Bogliani (University of Pavia) for the support and contribution to the research programme. They also thank Roberta Sciascia, Mara Baudena and several field assistants for help during the sampling campaign and the Park wardens for their help and hospitality. Logistic sup- port was provided by the Gran Paradiso National Park.

Funding for this research was provided by Gran Paradiso National Park and ISAC-CNR in the framework of the EU FP7 IP ACQWA project (Assessment of Climatic change and impacts on the Quantity and quality of Water), Grant Agreement No. 212250. Supplemental funding for the chemical analyses was provided by ISE-CNR (Pallanza), whereas deposition data collection and analysis were funded by the European Union, through the project LIFE07 ENV/D/000218 FutMon (Further Development and Implementation of an EU-level Forest Monitoring System).

\section{REFERENCES}

Allott TEH, Curtis CJ, Hall J, Harriman R, Battarbee RW, 1995. The impact of nitrogen deposition on upland surface waters in Great Britain: a regional assessment of nitrate leaching. Water Air Soil Poll. 85:297-302.

Bahls PF, 1992. The status of fish population and management of high mountain lakes in western United States. Northwest Sci. 66:183-193.

Boavida MJ, Gliwicz ZM, 1996. Limnological and biological characteristics of the Alpine lakes of Portugal. Limnetica 12:39-45.

Brandl Z, 1998. Feeding strategies of planktonic cyclopoids in lacustrine ecosystems. J. Marine Syst. 15:87-95.

Brandl Z, 2005. Freshwater copepods and rotifers: predators and their prey. Hydrobiologia 546:475-489.

Callieri C, Bertoni R, 1999. Organic carbon and microbial food web assemblages in an oligotrophic Alpine lake. J. Limnol. 58:136-143.

Callieri C, Corno G, Bertoni R, 2006. Bacterial grazing by mixotrophic flagellates and Daphnia longispina: a comparison in a fishless Alpine lake. Aquat. Microb. Ecol. 42:127-137.

Callieri C, Morabito G, Huot Y, Neale PJ, Litchman E, 2001. Photosynthetic response of pico- and nanoplanktonic algae to UVB, UVA and PAR in a high mountain lake. Aquat. Sci. 63:286-293.

Capblancq J, Laville H, 1983. [Le lac de Port-Bielh (Pyrénées): example de fonctionnement d'un écosystème lacustre de haute montagne], p. 51-80. In: M. Lamotte and F. Bourliére $\mathrm{F}$ (eds.), [Problèmes d'écologie: structure et fonctionnement des écosystèmes limniques]. [Book in French]. Masson.

Catalan J, Camarero L, Felip M, Pla S, Ventura M, Buchaca T, Bartumeus F, de Mendoza G, Miró A, Casamayor EO, Medina-Sánchez JM, Bacardit M, Altuna M, Bartrons M, de Quijano DD, 2006. High mountain lakes: extreme habitats and witnesses of environmental changes. Limnetica 25:551-584.

CIPRA, 1992. [Gli ultimi fiumi naturali delle Alpi]. [Book in Italian]. CIPRA Internationale Alpenschutzkommission Publ., Vaduz: $71 \mathrm{pp}$.

Compagnoni R, Elter G, Lombardo B, 1974. [Eterogeneità stratigrafica del complesso degli "Gneiss Minuti" nel massiccio cristallino del Gran Paradiso]. [Article in Italian]. Mem. Soc. Geol. It. 13:227-239.

Dumont HJ, Van de Velde I, Dumont S, 1975. The dry weight estimate of biomass in a selection of Cladocera, Copepoda and Rotifera from the plankton, periphyton and benthos of continental waters. Oecologia 19:75-97.

Eby LA, Roach WJ, Crowder LB, Stanford JA, 2006. Effects of 
stocking-up freshwater food webs. Trends Ecol. Evol. 21:576584.

Edmondson WT, Winberg GG, 1971. A manual on methods for the assessment of secondary productivity in fresh waters. IBP Handbook 17. Blackwell Scientific Pubblications, Oxford: 500 pp.

Ellis BK, Stanford JA, Craft JA, Chess DW, Hauer FR, Whited DC, 2003. Plankton communities of Alpine and subalpine lakes in Glacier National Park, Montana, U.S.A., 1984 - 1990. Verh. Internat. Verein. Limnol. 28:1542-1550.

Evans CD, Cullen JM, Alewell C, Kopácek J, Marchetto A, Moldan F, Prechtel A, Rogora M, Veselý J, Wright R, 2001. Recovery from acidification in European surface waters. Hydrol. Earth Syst. Sc. 5:283-297.

Frei C, Schär C, 1998. A precipitation climatology of the Alps from high-resolution rain-gauge observations. Int. J. Climatol. 18:873-900.

Godlewska M, Mazurkiewicz-Boroń G, Pociecha A, Wilk-Woźniak E, Jelonek M, 2003. Effects of flood on the functioning of the Dobczyce reservoir ecosystem. Hydrobiology 504:305313.

Goldman CR, Home AJ, 1983. Limnology. McGraw-Hill, New York: 384 pp.

Hansson LA, 1996. Algal recruitment from lake sediments in relation to grazing, sinking, and dominance patterns in the phytoplankton community. Limnol. Oceanogr. 41:1312-1323.

Hansson LA, Hylander S, 2009. Effects of ultraviolet radiation on pigmentation, photoenzymatic repair, behavior, and community ecology of zooplankton. Photoch. Photobio. Sci. 8:12661275.

Hedin LO, Armesto JJ, Johnson AH, 1995. Patterns of nutrient loss from unpolluted, old-growth temperate forests: evaluation of biogeochemical theory. Ecology 76:493-509.

Hillebrand H, Dürselen CD, Kirschtel D, Pollingher U, Zohary T, 1999. Biovolume calculation for pelagic and benthic microalgae. J. Phycol. 35:403-424.

Hinder B, Baur I, Hanselmann K, Schanz F, 1999. Microbial food web in an oligotrophic high mountain lake (Jöri lake III, Switzerland). J. Limnol. 58:162-168.

Kaushal SS, Lewis WMJ, 2003. Patterns in the chemical fractionation of organic nitrogen in Rocky Mountain streams. Ecosystems 6:483-492.

Kopácek J, Veselý J, Stuchlík E, 2001. Sulphur and nitrogen fluxes and budgets in the Bohemian Forest and Tatra Mountains during the Industrial Revolution (1850-2000). Hydrol. Earth Syst. Sc. 5:391-406.

Kruk C, Huszar VLM, Peeters ETHM, Bonilla S, Costa L, Lürling M, Reynolds CS, Scheffer M, 2010. A morphological classification capturing functional variation in phytoplankton. Freshwater Biol. 55:614-627.

Lampert W, Fleckner W, Rai H, Taylor BE, 1986. Phytoplankton control by grazing zooplankton: a study on the spring clearwater phase. Limnol. Oceanogr. 31:478-490.

Legner M, Sprules WG, 1993. Preservation and computer aided microscopic analysis of planktonic protozoa and algae. J. Aquat. Ecosyst. Health 2:221-227.

Litchman E, Klausmeier CA, 2008. Trait-based community ecology of phytoplankton. Annu. Rev. Ecol. Evol. S. 39:615-639.

Loferer-Krößbacher M, Klima J, Psenner R, 1998. Determination of bacterial cell dry mass by transmission electron microscopy and densitometric image analysis. Appl. Environ. Microb. 64:688-694.

Madigan MT, Martinko JM, Dunlap PV, Clark DP, 2009. Brock biology of microorganisms, $12^{\text {th }}$ ed. Pearson, San Francisco: $1168 \mathrm{pp}$.

Magnea U, Sciascia R, Paparella F, Tiberti R, Provenzale A, 2013. A model for high-altitude Alpine lake ecosystems and the effect of introduced fish. Ecol. Model. 251:211-220.

Manca M, Comoli P, 1999. Studies on zooplankton of Lago Paione Superiore. J. Limnol. 58:131-135.

Marchetto A, Mosello R, Psenner R, Bendetta G, Boggero A, Tait D, Tartari GA, 1995. Factors affecting water chemistry of Alpine lakes. Aquat. Sci. 57:81-89.

Marchetto A, Mosello R, Tartari GA, Derome K, König N, Clarke N, Kowalska A, 2010. Atmospheric deposition and soil solution, Working Ring Test 2010. Laboratory ring test for deposition and soil solution sample analyses for the laboratories participating in the EU/Life+ FutMon Project. CNR-ISE Publ., Pallanza: 59 pp.

Mcknight DM, Smith RL, Bradbury JP, Baron JS, Spaulding S, 1990. Phytoplankton dynamics in three Rocky mountain lakes, Colorado, U.S.A. Arctic Alpine Res. 22:264-274.

Mills KH, Schlinder DW, 1986. Biological indicators of lake acidification. Water Air Soil Poll. 30:779-789.

Mosello R, Lami A, Guilizzoni P, Manca M, Nocentini AM, Pugnetti A, Boggero A, Marchetto A, Tartari GA, Bettinetti R, Bonardi M, Cammarano P, 1992. Limnological studies on two acid sensitive lakes in the South Western Alps (lakes Paione Superiore and Paione Inferiore, Italy). Mem. Ist. Ital. Idrobiol. 51:127-146.

Murphy CA, Thompson PL, Vinebrooke RD, 2010. Assessing the sensitivity of Alpine lakes and ponds to nitrogen deposition in the Canadian Rocky Mountains. Hydrobiologia 648:83-90.

Naselli-Flores L, Padisák J, Dokulil MT, Chorus I, 2003. Equilibrium/steady-state concept in phytoplankton ecology. Hydrobiologia 502:395-403.

Ohlendorf C, Bigler C, Goudsmit GH, Lemcke G, Livingstone DM, Lotter AF, Müller B, Sturm M, 2000. Causes and effects of long periods of ice cover on a remote high Alpine lake. J. Limnol. 59:65-80.

Ørbæk JB, Kallenborn R, Tombre I, Hegseth EN, Falk-Petersen S, Hoel AH, 2007. Arctic Alpine ecosystems and people in a changing environment. Springer, Heidelberg: $434 \mathrm{pp}$.

O'Sullivan PE, Reynolds CS, 2004. The lakes handbook. Limnology and limnetic ecology. 1. Blackwell Publishing, Oxford: $699 \mathrm{pp}$.

Pace ML, Orcutt JD, 1981. The relative importance of protozoans, rotifers and crustaceans in a freshwater zooplankton community. Limnol. Oceanogr. 26:822-830.

Pechlaner R, Bretschko G, Gollmann P, Pfeifer H, Tilzer M, Weissenbach HP, 1970. The production process in two high mountain lakes (Vorderer and Hinterer Finstertaler See, Kütai, Austria), p. 237-267. In: Z. Kajak Z and A. HillbrichtIlkowska (eds.), Productivity problems in freshwaters. PWN - Polish Scientific Publ.

Pienitz R, Smol JP, Lean DRS, 1997a. Physical and chemical limnology of 59 lakes located between the southern Yukon and the Tuktoyaktuk Pninsula, Northwest Territories (Canada). Can. J. Fish. Aquat. Sci. 54:330-346.

Pienitz R, Smol JP, Lean DRS, 1997b. Physical and chemical lim- 
nology of 24 lakes located between Yellowknife and Contwoyto lake, Northwest Territories (Canada). Can. J. Fish. Aquat. Sci. 54:347-358.

Posch T, Loferer-Krößbacher M, Gao G, Alfreider A, Pernthaler J, Psenner R, 2001. Precision of bacterioplankton biomass determination: a comparison of two fluorescent dyes, and of allometric and linear volume-to-carbon conversion factors. Aquat. Microb. Ecol. 25:55-63.

Reynolds CS, 2006. The ecology of phytoplankton. Cambridge University Press, Cambridge: 552 pp.

Reynolds CS, 2007. Variability in the provision and function of mucilage in phytoplankton: facultative responses to the environment. Hydrobiologia 578:37-45.

Rogora M, Marchetto A, Mosello R, 2001. Trends in the chemistry of atmospheric deposition and surface waters in the lake Maggiore catchment. Hydrol. Earth Syst. Sc. 5:379-390.

Rogora M, Massaferro J, Marchetto A, Tartari GA, Mosello R, 2008. The water chemistry of some shallow lakes in Northern Patagonia and their nitrogen status in comparison with remote lakes in different regions of the globe. J. Limnol. 67:75-86.

Rogora M, Mosello R, Arisci S, 2003. The effect of climate warming on the hydrochemistry of Alpine lakes. Water Air Soil Poll. 148:347-361.

Rogora M, Mosello R, Arisci S, Brizzio MC, Barbieri A, Balestrini R, Waldner P, Schmitt M, Stahli M, Thimonier A, Kalina M, Puxbaum H, Nickus U, Ulrich E, Probst A, 2006. An overview of atmospheric deposition chemistry over the Alps: present status and long-term trends. Hydrobiologia 562:17-40.

Rott E, 1988. Some aspects of the seasonal distribution of flagellates in mountain lakes. Hydrobiologia 161:159-170.

Ruttner-Kolisko A, 1977. Suggestions for biomass calculations of plankton rotifers. Arch. Hydrobiol. 8:71-76.

Rzychon D, Worsztynowicz A, 2008. What affects nitrogen retention in Tatra Mountains lakes' catchments in Poland? Hydrol. Earth Syst. Sc. 12:415-424.

Salcher MM, Pernthaler J, Posch T, 2010. Spatiotemporal distribution and activity patterns of bacteria from three phylogenetic groups in an oligomesotrophic lake. Limnol. Oceanogr. 55:846-856.

Salonen K, Lepparanta M, Viljanen M, Gulati RD, 2009. Perspectives in winter limnology: closing the annual cycle of freezing lakes. Aquat. Ecol. 43:609-616.

Schindler DW, Noven B, 1971. Vertical distribution and seasonal abundance of zooplankton in two shallow lakes of the Experimental lakes Area, Northwestern Ontario. J. Fish. Res. Board Can. 28:245-256.

Sommer U, Gliwicz ZM, Lampert W, Duncan A, 1986. The PEG-model of seasonal succession of planktonic events in fresh waters. Arch. Hydrobiol. 106:433-471.

Straile D, 2005. Food webs in lakes-seasonal dynamics and impact of climate variability, p. 41-50. In: A. Belgrano, U.M. Schaler, J. Dunne, R.E. Ulanowicz (eds.), Aquatic food webs: an ecosystem approach. Oxford University Press.

Straškrabová V, Callieri C, Fott J, (eds.) 1999a. Pelagic food web in mountain lakes. Mountain Lakes Research Program. J. Limnol. 58:77-222.
Straškrabová V, Callieri C, Carrillo P, Cruz-Pizarro L, Fott J, Hartman P, Macek M, Medina-Sánchez JM, Nedoma J, Šimek K, 1999b. Investigations on pelagic food webs in mountain lakes - aims and methods. J. Limnol. 58:77-87.

Tartari GA, Mosello R, 1997. [Metodologie analitiche e controlli di qualità nel laboratorio chimico dell'Istituto Italiano di Idrobiologia del Consiglio Nazionale delle Ricerche]. [Article in Italian]. Documenta Ist. Ital. Idrobiol. 60:1-160.

Tartari GA, Tartari G, Mosello R, 1998. Water chemistry of high altitude lakes in the Khumbu and Imja Kola valleys (Nepalese Himalayas). Mem. Ist. Ital. Idrobiol. 57:51-76.

Tiberti R, 2011. Morphology and ecology of Daphnia middendorffiana, Fisher 1851 (Crustacea, Daphniidae) from four new populations in the Alps. J. Limnol. 70:239-247.

Tiberti R, Iacobuzio R, 2013. Does fish predation influence the vertical distribution of zooplankton in high transparency lakes? Hydrobiologia 709:27-39.

Tiberti R, Tartari GA, Marchetto A, 2010. Geomorphology and hydrochemistry of 12 Alpine lakes in the Gran Paradiso National Park, Italy. J. Limnol. 69:242-256.

Tilzer M, Schwarz K, 1976. Seasonal and vertical patterns of phytoplankton light adaptation in a high mountain lake. Arch. Hydrobiol. 77:488-504.

Tolotti M, Manca M, Angeli N, Morabito G, Thaler B, Rott E, Stuchlik E, 2006. Phytoplankton and zooplankton associations in a set of Alpine high altitude lakes: geographic distribution and ecology. Hydrobiologia 562:99-122.

Turner RS, Johnson DW, Elwood JW, Van Winkle W, Clapp RB, 1986. Factors affecting response of surface waters to acidic deposition. Oak Ridge National Laboratory ed., Corvallis: 152 $\mathrm{pp}$.

Vadstein O, 2000. Heterotrophic planktonic bacteria and cycling of phosphorus: phosphorus requirements, competitive ability, and food web interactions, p. 115-167. In: B. Schink (ed.), Advances in microbial ecology. Kluwer Academic Publisher.

Ventura M, Camarero L, Buchaca T, Bartumeus F, Livingstone DM, Catalan J, 2000. The main features of seasonal variability in the external forcing and dynamics of a deep mountain lake (Redó, Pyrenees). J. Limnol. 59:97-108.

Vidal J, 1980. Physioecology of zooplankton. I. Effects of phytoplankton concentration, temperature, and body size on the growth rate of Calanus pacificus and Pseudocalanus sp. Mar. Biol. 56:111-134.

Vollenweider RA, 1974. A manual on methods for measuring primary production in aquatic environments. $2^{\text {nd }}$ ed., IBP Handbook 12. Blackwell Scientific Publ., Oxford: 213 pp.

Wille A, Sonntag B, Sattler B, Psenner R, 1999. Abundance, biomass and size structure of the microbial assemblage in the high mountain lake Gossenköllesee (Tyrol, Austria) during the ice-free period. J. Limnol. 58:117-126.

Winder M, Bürgi HR, Spaak P, 2003. Mechanisms regulating zooplankton populations in a high-mountain lake. Freshwater Biol. 48:795-809.

Wright RF, Larssen T, Camarero L, Cosby BJ, Ferrier RC, Helliwell R, Forsius M, Jenkins A, Kopácek J, Majer V, Moldan F, Posch M, Rogora M, Schöpp W, 2005. Recovery of acidified European surface waters. Environ. Sci. Technol. 39:64A$74 \mathrm{~A}$. 